\title{
PEMBUATAN FILM ANIMASI 2D GUNA PENGENALAN SILA DALAM PANCASILA
}

\author{
Yandi Arifin ${ }^{(1)}$,Afdhol Dzikri( ${ }^{(2)}$ \\ Teknik Informatika, Politeknik Negeri Batam \\ Jl.Ahmad Yani, Batam Kota, Kota Batam, Kepulauan Riau, 2946 I, Indonesia
}

Email: (I) YANDI.431I301015@student.polibatam.ac.id, (2) afdhol@polibatam.ac.id,

\begin{abstract}
Abstrak
Knowledge about Garuda Pancasila as a symbol of the Republic of Indonesia is very necessary to be learned as early as possible. Various learning methods have been used in order to introduce the Garuda Pancasila to the community, especially elementary school students. But sometimes these methods make students feel bored quickly so they are not serious in carrying out the learning process. Therefore, we need media that can entertain and provide education to the students. By using $2 D$ animation, it is expected that the learning process can be conveyed in a more fun and enjoyable way. For this reason, a 2D animation film was made as a learning medium to introduce the symbol of the country. The process of making this $2 D$ animated film becomes more focused by using the Godfrey method. A method of testing in the form of a survey was conducted to elementary school students about messages conveyed in the $2 D$ animated film. The results of the test proved that the film is an effective learning medium to convey the moral messages about the importance of knowing the symbol of the country and the values contained therein for children.
\end{abstract}

Keywords : Garuda Pancasila, learning media, 2D animation, Godfrey method

\section{PENDAHULUAN}

Pancasila telah ditetapkan sebagai dasar negara dan telah diterima oleh seluruh warga negara Indonesia seperti yang tercantum pada pembukaan Undang- Undang dasar 1945 yang merupakan kepribadian negara dan cara pandang hidup bangsa yang telah diuji kebenaran dan kemampuannya sehingga tak ada satu kekuatan apapun dan manapun juga yang mampu memisahkan Pancasila dan Indonesia dari kehidupan masyarakat Indonesia (Hadnomo, 2011). Garuda Pancasila merupakan lambang Negara Republik Indonesia. Hal ini tercantum dalam Undang Undang Dasar (UUD) 1945 dan Peraturan Pemerintah No. 66 Tahun 1951. Pada perisai Garuda Pancasila terdapat lima buah ruang yang mewujudkan dasar negara Pancasila. (Budi, 2014).

Sila pertama Pancasila dilambangkan dengan bintang tunggal yang artinya menerangi dan memberikan cahaya bagi bangsa dan negara. Sila kedua dilambangkan dengan rantai emas yang melambangkan bahwa setiap manusia, laki-laki dan perempuan, saling membutuhkan satu sama lain dan perlu bersatu sehingga menjadi kuat seperti sebuah rantai. Sila ketiga dilambangkan dengan pohon beringin, seperti keanekaragaman suku dan bangsa Indonesia yang harus selalu bersatu. Sila keempat dilambangkan dengan kepala banteng; banteng adalah hewan yang memiliki jiwa sosial yang tinggi dan suka berkumpul. Sila kelima dilambangkan dengan padi dan 
kapas, yang melambangkan kebutuhan dasar manusia: padi yang menjadi dasar untuk makanan pokok dan kapas untuk kebutuhan dasar sandang (Kaharudin, 2015).

Namun, filosofi dan implementasi tentang Pancasila dan makna Lambang Garuda kurang dipahami oleh generasi muda menurut Virdianti (2014). Oleh karena itu, pengenalan makna-makna yang terkandung dalam setiap lambang Garuda Pancasila perlu dilakukan sedini mungkin. Agar generasi muda usia sekolah dasar tertarik untuk mempelajari makna-makna tersebut, dibutuhkan sebuah media informasi yang menarik dan mudah dipahami. Berbagai media dalam proses pembelajaran di sekolah muncul seiring perkembangan teknologi untuk menunjang metode penyampaian materi oleh guru guna memfasilitasi perkembangan potensi siswa, yang salah satunya berupa animasi 2D. Film animasi yang mengandung nilai pembelajaran layak untuk di pertontonkan kepada anak-anak, sebagai alat bantu pembelajaran yang dapat digunakan oleh guru maupun orang tua sehingga memberikan pengajaran yang lebih bervariasi. (Syafrudin dan Pujiono, 2013). Untuk itu, penelitian ini bertujuan untuk merancang dan membangun film animasi 2D sebagai media pembelajaran bagi siswa sekolah dasar usia 7-12 tahun dan menganalisis tingkat pemahaman mereka terhadap lambang Garuda Pancasila pada pembelajaran yang menggunakan film yang dibuat.

Secara harfiah, animasi berarti menghidupkan: usaha untuk menghidupkan dan menggerakan sesuatu yang tidak bisa bergerak sendiri (Buchari dkk, 2015). Animasi 2D adalah penciptaan gambar bergerak dalam lingkungan dua dimensi yang dilakukan dengan urutan gambar berturut-turut. Sebagai salah satu media hiburan, animasi dapat mempermudah pembuatan suatu adegan maupun karakter dalam pembuatan film sehingga dapat memberikan nilai pembelajaran dan pesan moral (Putra dan Purwanto, 2015). Dalam pengembangan multimedia dikenal metode Godfrey. Penelitian ini bertujauan merancang dan membangun film animasi 2 dimensi sebagai media pembelajaran menggunakan metode Godfrey.

\section{METODE}

Metode Godfrey merupakan turunan dari metode pengembangan perangkat lunak Waterfall. Sama dengan metode Waterfall, metode Godfrey memiliki urutan proses pengembangan multimedia dengan tujuan spesifik masing-masing, yang terdiri dari Problem Definition, Genre and Character, Location and Interface, Plotting, Scripting, Production and Testing, serta Use. Pada tahap Problem Definition ditentukan klien atau pengguna, kebutuhan, ruang lingkup, dan sumber daya. Genre dalam film yang dibuat masuk dalam kategori media pembelajaran. Genre menentukan audio, konsep warna, dan tipografi yang akan digunakan dalam pembuatan film. Karakter utama dalam dalam film ini terdiri dari Garda, Doni, dan Putri. Pada tahap Location ditentukan tata letak yang diawali dengan pembuatan sketsa sebagai acuan yang kemudian diimplementasikan pada produk yang dibuat. Tahap Interface melibatkan penentuan antarmuka yang disediakan untuk pengguna oleh pembuat produk berupa interaksi yang dapat diberikan baik berupa input maupun output. Tahap ini terkait dengan pembuatan storyboard. Pada tahap Plotting ditentukan jalannya sebuah cerita. Pada tahapan Scripting didefinisikan semua dialog yang ada, aksi dan reaksi alur cerita yang dibuat, serta tiap tahapan yang digunakan untuk seluruh interaksi. Tahap ini berkaitan erat dengan proses scriptwriting. Production and Testing terdiri dari tracing karakter, pewarnaan dan layering karakter, pembuatan set/latar, serta proses pembuatan animasi yang mencakup penambahan key animation dan classic tween.

Pada proses pembuatan film animasi 2D ini terdapat tiga tahapan, yang terdiri dari tahap pra-produksi, produksi, dan pasca-produksi. Pada proses tracing karakter, pewarnaan dan layering karakter, serta pembuatan 
set/latar dalam tahap produksi digunakan Adobe Illustrator, yang sangat populer dan sudah diakui kecanggihannya, serta sudah banyak dipakai oleh para desainer komputer karena keberadaannya benar-benar mampu membantu dan memudahkan pemakai dalam menyelesaikan pekerjaan desain grafis (Alfarisi, 2011). Selanjutnya, digunakan Adobe Flash. Tahap pasca-produksi meliputi penggabungan scene, penambahan efek dan transisi, penambahan audio, dan final rendering menggunakan software Adobe Premiere.

Terdapat dua cara pengujian yang dilakukan: terhadap hasil kuesioner dan terhadap kesesuaian scene. Pada cara pengujian dengan kuesioner, digunakan lima butir pertanyaan mengenai pendapat peserta, yang terdiri dari Ya (setuju) atau Tidak (tidak setuju), terkait film animasi yang dibuat, seperti dijabarkan dalam Tabel 1 berikut:

Tabel 1 Daftar Pertanyaan

\begin{tabular}{|l|}
\hline \multicolumn{1}{|c|}{ Daftar Pertanyaan } \\
\hline $\begin{array}{l}\text { 1. Menurut Kamu, apakah film animasi 2D "Pengenalan Lambang Garuda Pancasila" ini menarik? } \\
\text { terdengar dengan jelas? }\end{array}$ \\
\hline $\begin{array}{l}\text { 3. Menurut Kamu, apakah pesan pada film animasi 2D "Pengenalan Lambang Garuda Pancasila" ini dapat } \\
\text { dipahami? }\end{array}$ \\
$\begin{array}{l}\text { 4. Menurut Kamu, apakah film animasi 2D "Pengenalan Lambang Garuda Pancasila” ini dapat membantu } \\
\text { kamu dalam belajar mengenal lambang Garuda Pancasila? }\end{array}$ \\
\hline $\begin{array}{l}\text { 5. Menurut Kamu, apakah karakter Garda pada film animasi 2D "Pengenalan Lambang Garuda Pancasila" ini } \\
\text { berubah menjadi lebih baik? }\end{array}$ \\
\hline
\end{tabular}

Pengujian berdasarkan kesesuaian scene akan dijelaskan dalam bagian Hasil dan Pembahasan.

\section{HASIL DAN PEMBAHASAN}

Proses produksi yang dilalui terdiri dari tracing karakter, pewarnaan dan layering karakter, pembuatan set/latar, pembuatan animasi 2D, key animation, classic tween, penggabungan scene, penambahan efek dan transisi, penambahan audio, serta final rendering. Terdapat dua macam pengujian yang dilakukan, yaitu pengujian terhadap produk yang sudah jadi secara langsung menggunakan aplikasi pemutar video dengan melihat kesesuain scene yang ada dengan perancangan awal dan juga pengujian menggunakan kuisioner yang sudah dirancang. Terkait pengujian pertama, secara keseluruhan, terdapat 34 scene yang digabungkan pada pembuatan film animasi 2D pengenalan Lambang Garuda Pancasila ini.

Tabel 2 Kesesuaian Scene

\begin{tabular}{|c|l|l|l|}
\hline Scene & \multicolumn{1}{|c|}{ Keterangan } & Durasi & \multicolumn{1}{|c|}{ Audio } \\
\hline 1 shot & Sketsa menampilkan ayam berkokok di pagi hari. Setelah & 3 Detik & -Instrumen ayam \\
1 & tracing dan pewarnaan, dilakukan penganimasian dengan & & $\begin{array}{l}\text { berkokok } \\
\text { menggunakan teknik classic tween. }\end{array}$ \\
& -Backsound \\
\hline shot & Sketsa menampilkan rumah di pagi hari. Setelah tracing & 5 Detik & -Instrumen suara jangkrik \\
dan pewarnaan, dilakukan pergerakan awan dengan & & -Backsound \\
\hline
\end{tabular}




\begin{tabular}{|c|c|c|c|}
\hline Scene & Keterangan & Durasi & Audio \\
\hline & $\begin{array}{l}\text { teknik classic tween dan lampu menyala dengan teknik } \\
\text { key animation. }\end{array}$ & & \\
\hline $\begin{array}{c}3 \text { shot } \\
1\end{array}$ & $\begin{array}{l}\text { Sketsa menampilkan jam dinding. Setelah tracing dan } \\
\text { pewarnaan, dilakukan penganimasian terhadap jarum jam } \\
\text { dengan menggunakan teknik key animation. }\end{array}$ & 3 Detik & -Jam berdetak \\
\hline $\begin{array}{c}4 \text { shot } \\
1\end{array}$ & $\begin{array}{l}\text { Sketsa menampilkan ruang kamar tidur. Setelah tracing } \\
\text { dan pewarnaan, dilakukan penganimasian pada karakter } \\
\text { dengan menggunakan teknik key animation. }\end{array}$ & 3 Detik & -Backsound \\
\hline $\begin{array}{c}4 \text { shot } \\
2\end{array}$ & $\begin{array}{l}\text { Sketsa menampilkan suasana di depan pintu kamar. } \\
\text { Setelah tracing dan pewarnaan, dilakukan penganimasian } \\
\text { pada tangan dengan menggunakan teknik classic tween. }\end{array}$ & 5 Detik & $\begin{array}{l}\text {-Narasi Ibu } \\
\text { membangunkan Garda } \\
\text { untuk salat subuh. }\end{array}$ \\
\hline $\begin{array}{c}4 \text { shot } \\
3\end{array}$ & $\begin{array}{l}\text { Sketsa menampilkan tempat tidur. Setelah tracing dan } \\
\text { pewarnaan, dilakukan penganimasian pada mata dan } \\
\text { mulut dengan menggunakan teknik key animation. }\end{array}$ & 3 Detik & $\begin{array}{l}\text {-Narasi Garda menjawab } \\
\text { Ibu }\end{array}$ \\
\hline $\begin{array}{c}4 \text { shot } \\
4\end{array}$ & $\begin{array}{l}\text { Sketsa menampilkan ruang kamar tidur. Setelah tracing } \\
\text { dan pewarnaan, dilakukan penganimasian pada karakter } \\
\text { dengan menggunakan teknik key animation. }\end{array}$ & 3 Detik & -Backsound \\
\hline $\begin{array}{c}5 \text { shot } \\
1\end{array}$ & $\begin{array}{l}\text { Sketsa menampilkan rumah di pagi hari. Setelah tracing } \\
\text { dan pewarnaan, dilakukan penganimasian pada awan } \\
\text { yang bergerak dengan menggunakan teknik classic } \\
\text { tween. }\end{array}$ & 5 Detik & $\begin{array}{l}\text {-Isntrumen burung } \\
\text { berkicau } \\
\text {-Backsound }\end{array}$ \\
\hline $\begin{array}{c}6 \text { shot } \\
1\end{array}$ & $\begin{array}{l}\text { Sketsa menampilkan jam dinding. Setelah tracing dan } \\
\text { pewarnaan, dilakukan penganimasian pada jarum jam } \\
\text { dengan menggunakan teknik key animation. }\end{array}$ & 3 Detik & -Jam berdetak \\
\hline $\begin{array}{c}7 \text { shot } \\
1\end{array}$ & $\begin{array}{l}\text { Sketsa menampilkan ruang kamar mandi. Setelah tracing } \\
\text { dan pewarnaan, dilakukan penganimasian pada mata dan } \\
\text { pergerakan badan dengan menggunakan teknik key } \\
\text { animation. }\end{array}$ & 6 Detik & -Backsound \\
\hline $\begin{array}{c}7 \text { shot } \\
2\end{array}$ & $\begin{array}{l}\text { Sketsa menampilkan ruang kamar mandi. Setelah tracing } \\
\text { dan pewarnaan, dilakukan penganimasian terhadap } \\
\text { tangan serta air mengalir dengan menggunakan teknik } \\
\text { key animation. }\end{array}$ & 3 Detik & $\begin{array}{l}\text {-Isntrumen air } \\
\text {-Backsound }\end{array}$ \\
\hline $\begin{array}{c}8 \text { shot } \\
1\end{array}$ & $\begin{array}{l}\text { Sketsa menampilkan ruang kamar tidur. Setelah tracing } \\
\text { dan pewarnaan, dilakukan penganimasian pada mata dan } \\
\text { tubuh dengan menggunakan teknik key animation. }\end{array}$ & 6 Detik & -Backsound \\
\hline $\begin{array}{c}9 \text { shot } \\
1\end{array}$ & $\begin{array}{l}\text { Sketsa menampilkan jam dinding. Setelah tracing dan } \\
\text { pewarnaan, dilakukan penganimasian pada jarum jam } \\
\text { dengan menggunakan teknik key animation. }\end{array}$ & 3 Detik & -Jam berdetak \\
\hline
\end{tabular}




\begin{tabular}{|c|c|c|c|}
\hline Scene & Keterangan & Durasi & Audio \\
\hline $\begin{array}{c}9 \text { shot } \\
2\end{array}$ & $\begin{array}{l}\text { Sketsa menampilkan karakter. Setelah tracing dan } \\
\text { pewarnaan, dilakukan penganimasian pada background } \\
\text { dan karakter dengan menggunakan teknik classic tween. }\end{array}$ & 4 Detik & $\begin{array}{l}\text {-Narasi Garda pamit } \\
\text { pergi ke sekolah } \\
\text {-Backsound }\end{array}$ \\
\hline $\begin{array}{c}10 \\
\text { shot } 1\end{array}$ & $\begin{array}{l}\text { Sketsa menampilkan jalanan. Setelah tracing dan } \\
\text { pewarnaan, dilakukan penganimasian terhadap karakter } \\
\text { dan background menggunakan teknik key animation. }\end{array}$ & 2 Detik & -Backsound \\
\hline $\begin{array}{c}10 \\
\text { shot } 2\end{array}$ & $\begin{array}{l}\text { Sketsa menampilkan jalanan di pagi hari. Setelah tracing } \\
\text { dan pewarnaan, dilakukan penganimasian terhadap } \\
\text { background dan karakter dengan teknik classic tween. }\end{array}$ & 2 Detik & -Backsound \\
\hline $\begin{array}{c}10 \\
\text { shot } 3\end{array}$ & $\begin{array}{l}\text { Sketsa menampilkan jalanan di pagi hari. Setelah tracing } \\
\text { dan pewarnaan, dilakukan penganimasian pada karakter } \\
\text { pengemis dengan menggunakan teknik key animation. }\end{array}$ & 4 Detik & $\begin{array}{l}\text {-Narasi Pengemis } \\
\text { meminta tolong kepada } \\
\text { Garda } \\
\text {-Backsound }\end{array}$ \\
\hline $\begin{array}{c}10 \\
\text { shot } 4\end{array}$ & $\begin{array}{l}\text { Sketsa menampilkan jalanan di pagi hari. Setelah tracing } \\
\text { dan pewarnaan, dilakukan penganimasian pada karakter } \\
\text { Garda dengan menggunakan teknik key animation. }\end{array}$ & 4 Detik & $\begin{array}{l}\text {-Narasi Garda Menolak } \\
\text { menolong Pengemis } \\
\text {-Backsound }\end{array}$ \\
\hline $\begin{array}{c}10 \\
\text { shot } 5\end{array}$ & $\begin{array}{l}\text { Sketsa menampilkan gerbang sekolah. Setelah tracing } \\
\text { dan pewarnaan, dilakukan penganimasian pada } \\
\text { background dan karakter menggunakan teknik classic } \\
\text { tween. }\end{array}$ & 5 Detik & -Backsound \\
\hline $\begin{array}{c}11 \\
\text { shot } 1\end{array}$ & $\begin{array}{l}\text { Sketsa menampilkan lapangan upacara di pagi hari. } \\
\text { Setelah tracing dan pewarnaan, dilakukan penganimasian } \\
\text { pada background menggunakan teknik classic tween. }\end{array}$ & 5 Detik & -Backsound \\
\hline $\begin{array}{c}11 \\
\text { shot } 2\end{array}$ & $\begin{array}{l}\text { Sketsa menampilkan lapangan upacara. Setelah tracing } \\
\text { dan pewarnaan, dilakukan penganimasian pada } \\
\text { background serta pergerakan karakter dengan } \\
\text { menggunakan teknik classic tween. }\end{array}$ & 6 Detik & $\begin{array}{l}\text {-Narasi Garda terburu- } \\
\text { buru menuju barisan } \\
\text {-Backsound }\end{array}$ \\
\hline $\begin{array}{c}11 \\
\text { shot } 3\end{array}$ & $\begin{array}{l}\text { Sketsa menampilkan lapangan upacara. Setelah tracing } \\
\text { dan pewarnaan, dilakukan penganimasian pada mata dan } \\
\text { mulut karakter menggunakan teknik key animation. }\end{array}$ & 14 Detik & $\begin{array}{l}\text {-Narasi Garda bertanya } \\
\text { kepada Doni } \\
\text {-Narasi Doni membalas } \\
\text { pertanyaan Garda } \\
\text {-Backsound }\end{array}$ \\
\hline $\begin{array}{c}11 \\
\text { shot } 4\end{array}$ & $\begin{array}{l}\text { Sketsa menampilkan lapangan upacara. Setelah tracing } \\
\text { dan pewarnaan, dilakukan penganimasian pada karakter } \\
\text { dengan menggunakan teknik key animation. }\end{array}$ & 8 Detik & $\begin{array}{l}\text {-Narasi Putri melarang } \\
\text { untuk berbicara ketika } \\
\text { upacara } \\
\text {-Narasi Garda } \\
\text { membantah }\end{array}$ \\
\hline $\begin{array}{c}12 \\
\text { shot } 1\end{array}$ & $\begin{array}{l}\text { Sketsa menampilkan bel sekolah. Setelah tracing dan } \\
\text { pewarnaan, dilakukan penganimasian pada bunyi bel }\end{array}$ & 2 Detik & -instrumen bel \\
\hline
\end{tabular}




\begin{tabular}{|c|c|c|c|}
\hline Scene & Keterangan & Durasi & Audio \\
\hline & dengan menggunakan teknik classic tween. & & \\
\hline $\begin{array}{c}13 \\
\text { shot } 1\end{array}$ & $\begin{array}{l}\text { Sketsa menampilkan pintu masuk kelas. Setelah tracing } \\
\text { dan pewarnaan, dilakukan penganimasian pada } \\
\text { background dan karakter menggunakan teknik key } \\
\text { animation. }\end{array}$ & 6 Detik & -Backsound \\
\hline $\begin{array}{c}14 \\
\text { shot } 1\end{array}$ & $\begin{array}{l}\text { Sketsa menampilkan ruang kelas. Setelah tracing dan } \\
\text { pewarnaan, dilakukan penganimasian pada tangan, mulut, } \\
\text { mata karakter guru dengan menggunakan teknik key } \\
\text { animation. }\end{array}$ & 5 Detik & $\begin{array}{l}\text {-Narasi Ibu Guru } \\
\text { memulai pembelajaran } \\
\text {-Backsound }\end{array}$ \\
\hline $\begin{array}{c}15 \\
\text { shot } 1\end{array}$ & $\begin{array}{l}\text { Sketsa menampilkan bel sekolah. Setelah tracing dan } \\
\text { pewarnaan, dilakukan penganimasian pada bunyi bel } \\
\text { dengan menggunakan teknik classic tween. }\end{array}$ & 4 Detik & Instrumen bel \\
\hline $\begin{array}{c}16 \\
\text { shot } 1\end{array}$ & $\begin{array}{l}\text { Sketsa menampilkan kantin. Setelah tracing dan } \\
\text { pewarnaan, dilakukan penganimasian pada background } \\
\text { dengan menggunakan teknik classic tween. }\end{array}$ & 4 Detik & -Backsound \\
\hline $\begin{array}{c}16 \\
\text { shot } 2\end{array}$ & $\begin{array}{l}\text { Sketsa menampilkan ruang kantin. Setelah tracing dan } \\
\text { pewarnaan, dilakukan penganimasian pada mata, mulut } \\
\text { karakter ibu kantin dengan menggunakan teknik key } \\
\text { animation. }\end{array}$ & 18 Detik & $\begin{array}{l}\text {-percakapan antara Garda } \\
\text { dan Ibu Kantin } \\
\text {-Backsound }\end{array}$ \\
\hline $\begin{array}{c}17 \\
\text { shot } 1\end{array}$ & $\begin{array}{l}\text { Sketsa menampilkan halaman sekolah. Setelah tracing } \\
\text { dan pewarnaan, dilakukan penganimasian pada } \\
\text { background serta karakter menggunakan teknik classic } \\
\text { tween. }\end{array}$ & 7 Detik & -Backsound \\
\hline $\begin{array}{c}17 \\
\text { shot } 2\end{array}$ & $\begin{array}{l}\text { Sketsa menampilkan halaman sekolah. Setelah tracing } \\
\text { dan pewarnaan, dilakukan penganimasian pada } \\
\text { pergerakan } \\
\text { badan karakter menggunakan teknik classic tween. }\end{array}$ & 4 Detik & $\begin{array}{l}\text {-Narasi Garda memanggil } \\
\text { Putri dan Doni } \\
\text {-Backsound }\end{array}$ \\
\hline $\begin{array}{c}17 \\
\text { shot } 3\end{array}$ & $\begin{array}{l}\text { Sketsa menampilkan halaman sekolah. Setelah tracing } \\
\text { dan pewarnaan, dilakukan penganimasian pada mata, } \\
\text { mulut karakter Garda dengan menggunakan teknik key } \\
\text { animation. }\end{array}$ & 3 Detik & $\begin{array}{l}\text {-Percakapan Garda, Doni, } \\
\text { dan Putri } \\
\text {-Backsound }\end{array}$ \\
\hline $\begin{array}{c}17 \\
\text { shot } 4\end{array}$ & $\begin{array}{l}\text { Sketsa menampilkan halaman sekolah. Setelah tracing } \\
\text { dan pewarnaan, dilakukan penganimasian pada mata, } \\
\text { mulut karakter Doni menggunakan teknik key animation. }\end{array}$ & 14 Detik & $\begin{array}{l}\text {-Percakapan Garda, Doni, } \\
\text { dan Putri } \\
\text {-Backsound }\end{array}$ \\
\hline $\begin{array}{c}17 \\
\text { shot } 5\end{array}$ & $\begin{array}{l}\text { Sketsa menampilkan halaman sekolah. Setelah tracing } \\
\text { dan pewarnaan, dilakukan penganimasian pada mata, } \\
\text { mulut karakter Garda menggunakan teknik key } \\
\text { animation. }\end{array}$ & 10 Detik & $\begin{array}{l}\text {-Percakapan Garda, Doni, } \\
\text { dan Putri } \\
\text {-Backsound }\end{array}$ \\
\hline 17 & Sketsa menampilkan halaman sekolah. Setelah tracing & 6 Detik & -Percakapan Garda, \\
\hline
\end{tabular}




\begin{tabular}{|c|c|c|c|}
\hline Scene & Keterangan & Durasi & Audio \\
\hline shot 6 & $\begin{array}{l}\text { dan pewarnaan, dilakukan penganimasian pada mata, } \\
\text { mulut karakter Putri menggunakan teknik key animation. }\end{array}$ & & $\begin{array}{l}\text { Doni, dan Putri } \\
\text {-Backsound }\end{array}$ \\
\hline $\begin{array}{c}17 \\
\text { shot } 7\end{array}$ & $\begin{array}{l}\text { Sketsa menampilkan halaman sekolah. Setelah tracing } \\
\text { dan pewarnaan, dilakukan penganimasian pada mata, } \\
\text { mulut karakter Garda menggunakan teknik key } \\
\text { animation. }\end{array}$ & 7 Detik & $\begin{array}{l}\text {-Percakapan Garda, Doni, } \\
\text { dan Putri } \\
\text {-Backsound }\end{array}$ \\
\hline $\begin{array}{c}17 \\
\text { shot } 8\end{array}$ & $\begin{array}{l}\text { Sketsa menampilkan halaman sekolah. Setelah tracing } \\
\text { dan pewarnaan, dilakukan penganimasian pada mata, } \\
\text { mulut karakter Putri menggunakan teknik key animation. }\end{array}$ & 4 Detik & $\begin{array}{l}\text {-Percakapan Garda, } \\
\text { Doni, dan Putri } \\
\text {-Backsound }\end{array}$ \\
\hline $\begin{array}{c}17 \\
\text { shot } 9\end{array}$ & $\begin{array}{l}\text { Sketsa menampilkan halaman sekolah. Setelah tracing } \\
\text { dan pewarnaan, dilakukan penganimasian pada mata, } \\
\text { mulut karakter Garda menggunakan teknik key } \\
\text { animation. }\end{array}$ & 4 Detik & $\begin{array}{l}\text {-Percakapan Garda, Doni, } \\
\text { dan Putri } \\
\text {-Backsound }\end{array}$ \\
\hline $\begin{array}{c}17 \\
\text { shot } \\
10\end{array}$ & $\begin{array}{l}\text { Sketsa menampilkan halaman sekolah. Setelah tracing } \\
\text { dan pewarnaan, dilakukan penganimasian pada mata, } \\
\text { mulut karakter Putri menggunakan teknik key animation. }\end{array}$ & 2 Detik & $\begin{array}{l}\text {-Percakapan Garda, Doni, } \\
\text { dan Putri } \\
\text {-Backsound }\end{array}$ \\
\hline $\begin{array}{c}18 \\
\text { shot } 1\end{array}$ & $\begin{array}{l}\text { Sketsa menampilkan bel sekolah. Setelah tracing dan } \\
\text { pewarnaan, dilakukan penganimasian pada bunyi bel } \\
\text { dengan menggunakan teknik classic tween. }\end{array}$ & 2 Detik & Instrumen bel \\
\hline $\begin{array}{c}19 \\
\text { shot } 1\end{array}$ & $\begin{array}{l}\text { Sketsa menampilkan ruang kelas. Setelah tracing dan } \\
\text { pewarnaan, dilakukan penganimasian pada tangan, mata, } \\
\text { mulut karakter ibu guru dengan menggunakan teknik key } \\
\text { animation. }\end{array}$ & 6 Detik & $\begin{array}{l}\text {-Narasi Ibu Guru } \\
\text { menjelaskan pelajaran } \\
\text { selanjutnya } \\
\text {-Backsound }\end{array}$ \\
\hline $\begin{array}{c}19 \\
\text { shot } 2\end{array}$ & $\begin{array}{l}\text { Sketsa menampilkan ruang kelas. Setelah tracing dan } \\
\text { pewarnaan, dilakukan penganimasian pada mata dan } \\
\text { mulut karakter ibu dengan menggunakan teknik key } \\
\text { animation. }\end{array}$ & 11 Detik & $\begin{array}{l}\text {-Narasi Ibu Guru } \\
\text { menjelaskan pelajaran } \\
\text { selanjutnya } \\
\text {-Backsound }\end{array}$ \\
\hline $\begin{array}{c}20 \\
\text { shot } 1\end{array}$ & $\begin{array}{l}\text { Sketsa menampilkan ruang kelas. Setelah tracing dan } \\
\text { pewarnaan, dilakukan penganimasian pada mata dan } \\
\text { mulut karakter ibu guru dengan menggunakan teknik key } \\
\text { animation. }\end{array}$ & 9 detik & $\begin{array}{l}\text {-Narasi Ibu Guru } \\
\text { menjelaskan pelajaran } \\
\text { selanjutnya yaitu } \\
\text { kewarganegaraan } \\
\text {-Backsound }\end{array}$ \\
\hline $\begin{array}{c}20 \\
\text { shot } 2\end{array}$ & $\begin{array}{l}\text { Sketsa menampilkan papan tulis. Setelah tracing dan } \\
\text { pewarnaan, dilakukan penganimasian pada teks garuda } \\
\text { pancasila dengan menggunakan teknik key animation. }\end{array}$ & 8 Detik & $\begin{array}{l}\text {-Narasi Ibu Guru } \\
\text { menjelaskan Pancasila } \\
\text {-Backsound }\end{array}$ \\
\hline $\begin{array}{c}21 \\
\text { shot } 1\end{array}$ & $\begin{array}{l}\text { Sketsa menampilkan alam bebas dengan burung elang } \\
\text { rajawali. Setelah tracing dan pewarnaan, dilakukan } \\
\text { penganimasian pada mata serta pergerakan panah } \\
\text { menggunakan teknik key animation. }\end{array}$ & 21 Detik & $\begin{array}{l}\text {-Narasi Ibu Guru } \\
\text { menjelaskan Pancasila } \\
\text {-Backsound }\end{array}$ \\
\hline
\end{tabular}




\begin{tabular}{|c|c|c|c|}
\hline Scene & Keterangan & Durasi & Audio \\
\hline $\begin{array}{c}22 \\
\text { shot } 1\end{array}$ & $\begin{array}{l}\text { Sketsa menampilkan papan tulis. Setelah tracing dan } \\
\text { pewarnaan, dilakukan penganimasian pada text sila } \\
\text { pertama dengan menggunakan teknik key animation. }\end{array}$ & 8 Detik & $\begin{array}{l}\text {-Narasi Ibu Guru } \\
\text { menjelaskan sila Pertama } \\
\text {-Backsound }\end{array}$ \\
\hline $\begin{array}{c}22 \\
\text { shot } 2\end{array}$ & $\begin{array}{l}\text { Sketsa menampilkan bintang di langit malam. Setelah } \\
\text { tracing dan pewarnaan, dilakukan penganimasian pada } \\
\text { bintang serta anak panah menggunakan teknik classic } \\
\text { tween. }\end{array}$ & 46 Detik & $\begin{array}{l}\text {-Narasi Ibu Guru } \\
\text { menjelaskan sila Pertama } \\
\text {-Backsound }\end{array}$ \\
\hline $\begin{array}{c}22 \\
\text { shot } 3\end{array}$ & $\begin{array}{l}\text { Sketsa menampilkan ruang kelas. Setelah tracing dan } \\
\text { pewarnaan, dilakukan penganimasian pada karakter } \\
\text { Garda serta pemikirannya menggunakan teknik classic } \\
\text { tween. }\end{array}$ & 2 Detik & -instrumen terkejut \\
\hline $\begin{array}{c}23 \\
\text { shot } 1\end{array}$ & $\begin{array}{l}\text { Sketsa menampilkan papan tulis. Setelah tracing dan } \\
\text { pewarnaan, dilakukan penganimasian pada text sila kedua } \\
\text { dengan menggunakan teknik key animation. }\end{array}$ & 7 Detik & $\begin{array}{l}\text {-Narasi Ibu Guru } \\
\text { menjelaskan sila Kedua } \\
\text {-Backsound }\end{array}$ \\
\hline $\begin{array}{c}23 \\
\text { shot } 2\end{array}$ & $\begin{array}{l}\text { Sketsa menampilkan rantai emas dan orang yang } \\
\text { bergandengan tangan. Setelah tracing dan pewarnaan, } \\
\text { dilakukan penganimasian menggunakan teknik classic } \\
\text { tween. }\end{array}$ & 33 Detik & $\begin{array}{l}\text {-Narasi Ibu Guru } \\
\text { menjelaskan sila Kedua } \\
\text {-Backsound }\end{array}$ \\
\hline $\begin{array}{c}23 \\
\text { shot } 3\end{array}$ & $\begin{array}{l}\text { Sketsa menampilkan ruang kelas. Setelah tracing dan } \\
\text { pewarnaan, dilakukan penganimasian pada karakter } \\
\text { Garda serta pemikirannya menggunakan teknik classic } \\
\text { tween. }\end{array}$ & 3 Detik & -instrumen terkejut \\
\hline $\begin{array}{c}24 \\
\text { shot } 1\end{array}$ & $\begin{array}{l}\text { Sketsa menampilkan papan tulis. Setelah tracing dan } \\
\text { pewarnaan, dilakukan penganimasian pada text sila } \\
\text { ketiga dengan menggunakan teknik key animation. }\end{array}$ & 7 Detik & $\begin{array}{l}\text {-Narasi Ibu Guru } \\
\text { menjelaskan sila Ketiga } \\
\text {-Backsound }\end{array}$ \\
\hline $\begin{array}{c}24 \\
\text { shot } 2\end{array}$ & $\begin{array}{l}\text { Sketsa menampilkan pohon beringing. Setelah tracing } \\
\text { dan pewarnaan, dilakukan penganimasian pada } \\
\text { pergerakan panah dengan menggunakan teknik key } \\
\text { animation. }\end{array}$ & 51 Detik & $\begin{array}{l}\text {-Narasi Ibu Guru } \\
\text { menjelaskan sila Ketiga } \\
\text {-Backsound }\end{array}$ \\
\hline $\begin{array}{c}24 \\
\text { shot } 3\end{array}$ & $\begin{array}{l}\text { Sketsa menampilkan ruang kelas. Setelah tracing dan } \\
\text { pewarnaan, dilakukan penganimasian pada karakter } \\
\text { Garda serta pemikirannya menggunakan teknik classic } \\
\text { tween. }\end{array}$ & 3 Detik & -Instrumen terkejut \\
\hline $\begin{array}{c}25 \\
\text { shot } 1\end{array}$ & $\begin{array}{l}\text { Sketsa menampilkan papan tulis. Setelah tracing dan } \\
\text { pewarnaan, dilakukan penganimasian pada text sila } \\
\text { keempat dengan menggunakan teknik key animation. }\end{array}$ & 10 Detik & $\begin{array}{l}\text {-Narasi Ibu Guru } \\
\text { menjelaskan sila } \\
\text { Keempat } \\
\text {-Backsound }\end{array}$ \\
\hline $\begin{array}{c}25 \\
\text { shot } 2\end{array}$ & $\begin{array}{l}\text { Sketsa menampilkan banteng yang berkumpul. Setelah } \\
\text { tracing dan pewarnaan, dilakukan penganimasian pada }\end{array}$ & 38 Detik & $\begin{array}{l}\text {-Narasi Ibu Guru } \\
\text { menjelaskan sila }\end{array}$ \\
\hline
\end{tabular}




\begin{tabular}{|c|c|c|c|}
\hline Scene & Keterangan & Durasi & Audio \\
\hline & mata dan panah menggunakan teknik key animation. & & $\begin{array}{l}\text { Keempat } \\
\text {-Backsound }\end{array}$ \\
\hline $\begin{array}{c}25 \\
\text { shot } 3\end{array}$ & $\begin{array}{l}\text { Sketsa menampilkan ruang kelas. Setelah tracing dan } \\
\text { pewarnaan, dilakukan penganimasian pada karakter } \\
\text { Garda serta pemikirannya menggunakan teknik classic } \\
\text { tween. }\end{array}$ & 3 Detik & -Instrumen terkejut \\
\hline $\begin{array}{c}26 \\
\text { shot } 1\end{array}$ & $\begin{array}{l}\text { Sketsa menampilkan papan tulis. Setelah tracing dan } \\
\text { pewarnaan, dilakukan penganimasian pada text sila } \\
\text { kelima dengan menggunakan teknik key animation. }\end{array}$ & 11 Detik & $\begin{array}{l}\text {-Narasi Ibu Guru } \\
\text { menjelaskan sila Kelima } \\
\text {-Backsound }\end{array}$ \\
\hline $\begin{array}{c}26 \\
\text { shot } 2\end{array}$ & $\begin{array}{l}\text { Sketsa menampilkan padi dan kapas. Setelah tracing dan } \\
\text { pewarnaan, dilakukan penganimasian pada pergerakan } \\
\text { panah dengan menggunakan teknik key animation. }\end{array}$ & 32 Detik & $\begin{array}{l}\text {-Narasi Ibu Guru } \\
\text { menjelaskan sila Kelima } \\
\text {-Backsound }\end{array}$ \\
\hline $\begin{array}{c}26 \\
\text { shot } 3\end{array}$ & $\begin{array}{l}\text { Sketsa menampilkan ruang kelas. Setelah tracing dan } \\
\text { pewarnaan, dilakukan penganimasian pada karakter } \\
\text { Garda serta pemikirannya menggunakan teknik classic } \\
\text { tween. }\end{array}$ & 3 Detik & -Instrumen terkejut \\
\hline $\begin{array}{c}27 \\
\text { shot } 1\end{array}$ & $\begin{array}{l}\text { Sketsa menampilkan ruang kelas. Setelah tracing dan } \\
\text { pewarnaan, dilakukan penganimasian pada mata, mulut } \\
\text { karakter Garda dengan menggunakan teknik key } \\
\text { animation. }\end{array}$ & 4 Detik & $\begin{array}{l}\text {-Narasi garda ingin } \\
\text { berubah menjadi lebih } \\
\text { baik } \\
\text {-Backsound }\end{array}$ \\
\hline $\begin{array}{c}28 \\
\text { shot } 1\end{array}$ & $\begin{array}{l}\text { Sketsa menampilkan bel sekolah. Setelah tracing dan } \\
\text { pewarnaan, dilakukan penganimasian pada bunyi bel } \\
\text { dengan menggunakan teknik classic tween. }\end{array}$ & 2 Detik & -Instrumen bel \\
\hline $\begin{array}{c}29 \\
\text { shot } 1\end{array}$ & $\begin{array}{l}\text { Sketsa menampilkan ruang kelas. Setelah tracing dan } \\
\text { pewarnaan, dilakukan penganimasian pada mata, mulut } \\
\text { karakter ibu guru dengan menggunakan teknik key } \\
\text { animation. }\end{array}$ & 2 Detik & $\begin{array}{l}\text {-Narasi Ibu Guru } \\
\text { mempersilahkan pulang } \\
\text {-Backsound }\end{array}$ \\
\hline $\begin{array}{c}30 \\
\text { shot } 1\end{array}$ & $\begin{array}{l}\text { Sketsa menampilkan ruang kelas. Setelah tracing dan } \\
\text { pewarnaan, dilakukan penganimasian pada mata, mulut } \\
\text { karakter Garda dengan menggunakan teknik key } \\
\text { animation. }\end{array}$ & 4 Detik & $\begin{array}{l}\text {-Narasi Garda meminta } \\
\text { maaf kepada Doni dan } \\
\text { Putri } \\
\text {-Backsound }\end{array}$ \\
\hline $\begin{array}{c}30 \\
\text { shot } 2\end{array}$ & $\begin{array}{l}\text { Sketsa menampilkan ruang kelas. Setelah tracing dan } \\
\text { pewarnaan, dilakukan penganimasian pada mata, mulut } \\
\text { karakter Doni dengan menggunakan teknik key } \\
\text { animation. }\end{array}$ & 7 Detik & $\begin{array}{l}\text {-Percakapan Garda, Doni, } \\
\text { dan Putri } \\
\text {-Backsound }\end{array}$ \\
\hline $\begin{array}{c}30 \\
\text { shot } 3\end{array}$ & $\begin{array}{l}\text { Sketsa menampilkan ruang kelas. Setelah tracing dan } \\
\text { pewarnaan, dilakukan penganimasian pada mata, mulut } \\
\text { karakter Putri dengan menggunakan teknik key } \\
\text { animation. }\end{array}$ & 2 Detik & $\begin{array}{l}\text {-Percakapan Garda, Doni, } \\
\text { dan Putri } \\
\text {-Backsound }\end{array}$ \\
\hline
\end{tabular}




\begin{tabular}{|c|c|c|c|}
\hline Scene & Keterangan & Durasi & Audio \\
\hline $\begin{array}{c}30 \\
\text { shot } 4\end{array}$ & $\begin{array}{l}\text { Sketsa menampilkan ruang kelas. Setelah tracing dan } \\
\text { pewarnaan, dilakukan penganimasian pada mata, mulut } \\
\text { karakter Garda dengan menggunakan teknik key } \\
\text { animation. }\end{array}$ & 4 Detik & $\begin{array}{l}\text {-Percakapan Garda, Doni, } \\
\text { dan Putri } \\
\text {-Backsound }\end{array}$ \\
\hline $\begin{array}{c}30 \\
\text { shot } 5\end{array}$ & $\begin{array}{l}\text { Sketsa menampilkan ruang kelas. Setelah tracing dan } \\
\text { pewarnaan, dilakukan penganimasian pada mata, mulut } \\
\text { karakter Doni dan Putri dengan menggunakan teknik key } \\
\text { animation. }\end{array}$ & 3 Detik & $\begin{array}{l}\text {-Percakapan Garda, Doni, } \\
\text { dan Putri } \\
\text {-Backsound }\end{array}$ \\
\hline $\begin{array}{c}31 \\
\text { shot } 1\end{array}$ & $\begin{array}{l}\text { Sketsa menampilkan halaman sekolah. Setelah tracing } \\
\text { dan pewarnaan, dilakukan penganimasian pada } \\
\text { pergerakan karakter Doni dan Garda dengan } \\
\text { menggunakan teknik key animation. }\end{array}$ & 2 Detik & -Backsound \\
\hline $\begin{array}{c}32 \\
\text { shot } 1\end{array}$ & $\begin{array}{l}\text { Sketsa menampilkan ruang kamar tidur. Setelah tracing } \\
\text { dan pewarnaan, dilakukan penganimasian pada } \\
\text { background dengan menggunakan teknik classic tween. }\end{array}$ & 3 Detik & -Backsound \\
\hline $\begin{array}{c}33 \\
\text { shot } 1\end{array}$ & $\begin{array}{l}\text { Sketsa menampilkan jalanan. Setelah tracing dan } \\
\text { pewarnaan, dilakukan penganimasian pada background } \\
\text { dan karakter dengan menggunakan teknik classic tween. }\end{array}$ & 4 Detik & -Backsound \\
\hline $\begin{array}{c}34 \\
\text { shot } 1\end{array}$ & $\begin{array}{l}\text { Sketsa menampilkan kamar tidur. Setelah tracing dan } \\
\text { pewarnaan, dilakukan penganimasian pada pergerakan } \\
\text { karakter Garda dengan menggunakan teknik classic } \\
\text { tween. }\end{array}$ & 4 Detik & -Backsound \\
\hline
\end{tabular}

Pengujian menggunakan kuesioner dilakukan kepada siswa sekolah dasar usia 7-12 tahun. Survei dilaksanakan di SDN 008 Batam Kota dengan responden sebanyak 30 orang siswa kelas 3 SD. Pengujian ini dilakukan untuk mengetahui seberapa efektif menonton film animasi 2D Pengenalan Lambang Garuda Pancasila dapat membuat siswa tertarik untuk belajar dan membantu pengenalan Garuda Pancasila. Hasil pengujian disajikan dalam tabel 3.

Tabel 3 Hasil Kuesioner

\begin{tabular}{|c|c|c|c|}
\hline \multirow{2}{*}{ No } & \multirow{2}{*}{ Pertanyaan } & & \\
\hline & & Iya & Tidak \\
\hline 1 & $\begin{array}{l}\text { Menurut Kamu, apakah film animasi 2D "Pengenalan Lambang Garuda Pancasila" ini } \\
\text { menarik? }\end{array}$ & 30 & 0 \\
\hline 2 & $\begin{array}{l}\text { Menurut Kamu, apakah suara pada film animasi 2D "Pengenalan Lambang Garuda } \\
\text { Pancasila" ini dapat terdengar dengan jelas? }\end{array}$ & 24 & 6 \\
\hline 3 & $\begin{array}{l}\text { Menurut Kamu, apakah pesan pada film animasi 2D "Pengenalan Lambang Garuda } \\
\text { Pancasila" ini dapat dipahami? }\end{array}$ & 25 & 5 \\
\hline
\end{tabular}




\begin{tabular}{|l|l|c|}
\hline 4 & $\begin{array}{l}\text { Menurut Kamu, apakah film animasi 2D "Pengenalan Lambang Garuda Pancasila” ini } \\
\text { dapat membantu kamu dalam belajar mengenal lambang Garuda Pancasila? }\end{array}$ & 30 \\
\hline 5 & $\begin{array}{l}\text { Menurut Kamu, apakah karakter Garda pada film animasi 2D "Pengenalan Lambang } \\
\text { Garuda Pancasila" ini berubah menjadi lebih baik? }\end{array}$ & 30 \\
\hline
\end{tabular}

Dari hasil kuesioner, responden yang memberikan respon IYA pada pertanyaan pertama berjumlah 30 (100\%). Maka dapat disimpulkan bahwa film ini menarik sehingga membuat anak-anak usia 7-12 tahun menjadi tertarik untuk belajar mengenal lambang Garuda Pancasila serta nilai-nilai yang terkandung di dalamnya. Responden yang memberikan respon IYA berjumlah 24 (80\%) dan yang memberikan respon TIDAK sebanyak 6 (20\%). Maka dapat disimpulkan bahwa suara pada film sudah terdengar dengan jelas. Responden yang memberikan respon IYA pada pertanyaan ketiga berjumlah $25(83,3 \%)$ dan yang memberikan respon TIDAK sebanyak 5 (16,7\%). Maka dapat disimpulkan bahwa anak-anak dengan usia 7-12 tahun dapat memahami pesan yang disampaikan. Responden yang memberikan respon IYA pada pertanyaan keempat berjumlah 30 (100\%). Maka dapat disimpulkan bahwa sebagai salah satu media pembelajaran, film ini dapat membantu anak-anak usia 7-12 dalam belajar mengenal lambang Garuda Pancasila.

\section{KESIMPULAN}

Film animasi 2D pengenalan lambang Garuda Pancasila memiliki total scene 34 dan 72 shot dengan durasi 9 menit 20 detik. Proses produksi film ini menggunakan spesifikasi komputer standar yang menyebabkan proses produksi berjalan kurang lancar karena beberapa tahapan harus diulang dari awal akibat komputer yang sering gagal merespon. Hasil dari film ini, khususnya ketika sedang berjalan, masih terlihat patah-patah dan terdapat juga beberapa pergerakan yang belum halus.

Film animasi 2D pengenalan lambang Garuda Pancasila dapat memberikan pemahaman serta membantu proses pembelajaran terhadap siswa usia 7-12 tahun dalam mengenal lambang Garuda Pancasila, seperti yang telah ditunjukkan hasil survei pada pertanyaan nomor 3, dengan persentase sebesar 83,3\% dari responden yang menjawab IYA. Hal ini juga diperkuat dengan hasil survei pada pertanyaan nomor 4, dengan persentase $100 \%$ dari responden yang menjawab IYA. Film animasi yang dibangun dapat membantu memberikan pemahaman kepada siswa SD dalam pengenalan lambang Garuda Pancasila.

\section{DAFTAR PUSTAKA}

Alfarisi, M.S. (2011). Tracing Image dalam Dunia Digital Imaging. Dikutip dari http://www.slideshare.net/alfar151/image-tracing

Budi, W. (2014). Sejarah Arti Makna Lambang Garuda. Dikutip dari http://www.frewaremini.com/2014/01/sejarah-arti-makna-lambang-garuda.html

Buchari, M. Z., Sentinuwo, S. R., \& Lantang, O. A. (2015). Rancang Bangun Video Animasi 3 Dimensi Untuk Mekanisme Pengujian Kendaraan Bermotor di Dinas Perhubungan, Kebudayaan, Pariwisata, Komunikasi dan Informasi. Jurnal Teknik Informatika Universitas Sam Ratulangi, 6 (1).

Hadnomo, M.N.D. (2011). Makalah Pancasila "Pancasila Sebagai Dasar Negara”. Yogyakarta: STMIK “Amikom" Yogyakarta. 
Putra, H. M. \& Purwanto, A. (2015). Pembuatan Film Animasi 2D yang Berjudul Empat Monster Pada Komunitas Multimedia Amikom Surakarta. It Cida, 1 (1).

Kaharudin, Z. (2015). Arti dan makna Lambang Garuda Pancasila. Dikutip dari http://www.satujam.com/artilambang-pancasila/

Syafrudin, C. \& Pujiyono, W. (2013). Pembuatan Film Animasi Pendek "Dahsyatnya Sedekah" Berbasis Multimedia Menggunakan Teknik 2D Hybrid Animation dengan Pemanfaatan Graphic. Jurnal Sarjana Teknik Informatika, 1 (1).

Virdianti, P. (2014). Proses Penetapan Garuda Pancasila Sebagai Lambang Negara Indonesia Tahun 19491951. Surabaya: Fakultas Ilmu Sosial Universitas Negeri Surabaya. 